\title{
Post Occupancy Evaluation of School Refurbishment Projects: Multiple Case Study in the UK
}

\author{
Hamad Ahmed ${ }^{1}$, David J. Edwards ${ }^{1}{ }^{*}{ }^{\mathbb{D}}$, Joseph H. K. Lai ${ }^{2} \oplus$, Chris Roberts ${ }^{1}$, Caleb Debrah ${ }^{3}(\mathbb{D}$, \\ De-Graft Owusu-Manu ${ }^{4}$ and Wellington Didibhuku Thwala ${ }^{5}$ (i)
}

1 Faculty of Engineering and the Built Environment, Birmingham City University, City Centre Campus, Millennium Point, Birmingham B4 7XG, UK; hamad.ahmed2@mail.bcu.ac.uk (H.A.); chris.roberts@bcu.ac.uk (C.R.)

2 Department of Building Services Engineering, Hong Kong Polytechnic University, 11 Yuk Choi Rd, Hung Hom, Hong Kong; joseph.lai@polyu.edu.hk

3 Department of Building and Real Estate, Hong Kong Polytechnic University, Hung Hom, Hong Kong; caleb.debrah@connect.polyu.hk

4 Department of Construction Technology and Management, Kwame Nkrumah University of Science and Technology, Accra Rd, Kumasi AK-039-5028, Ghana; d.owusumanu@gmail.com

5 SARChi in Sustainable Construction Management and Leadership in the Built Environment, Faculty of Engineering and the Built Environment, University of Johannesburg, P.O. Box 524, Auckland Park, 2006 Johannesburg, South Africa; didibhukut@uj.ac.za

* Correspondence: drdavidedwards@aol.com

\section{check for} updates

Citation: Ahmed, H.; Edwards, D.J.; Lai, J.H.K.; Roberts, C.; Debrah, C.; Owusu-Manu, D.-G.; Thwala, W.D. Post Occupancy Evaluation of School Refurbishment Projects: Multiple Case Study in the UK. Buildings 2021, 11, 169. https://doi.org/10.3390/ buildings11040169

\section{Academic Editors:}

Agnieszka Leśniak, Krzysztof Zima and Wojciech Drozd

Received: 11 March 2021

Accepted: 9 April 2021

Published: 16 April 2021

Publisher's Note: MDPI stays neutral with regard to jurisdictional claims in published maps and institutional affiliations.

Copyright: (c) 2021 by the authors. Licensee MDPI, Basel, Switzerland. This article is an open access article distributed under the terms and conditions of the Creative Commons Attribution (CC BY) license (https:/ / creativecommons.org/licenses/by/ $4.0 /)$.

\begin{abstract}
Buildings inevitably deteriorate with time. Schools buildings are no exception and require refurbishment at times. Despite the UK Government announcing the $£ 1$ billion funding for rebuilding 50 schools over 10 years starting 2010-2021, it is common practice for builders and designers to, upon completion of a building project, move on to the next development without considering how the completed building performs. This research undertakes a post occupancy evaluation (POE) of three schools in the West Midlands, UK with specific focus on building services, viz., heating, lighting, and air conditioning and ventilation. The research adopted a mixed philosophical approach of interpretivism and post-positivism to conduct inductive reasoning. A questionnaire that collected both quantitative and qualitative primary data was distributed to the end-users of the schools. Data was analysed using the Cronbach's alpha, one sample $t$-test and Kruskal-Wallis test to identify any differences between the questionnaire responses. Findings revealed that building users demanded greater control of the internal environment thus contradicting the current trend for automated 'intelligent systems' approaches. This research represents the first work to consider the contractor's perspective towards developing a better understanding of client satisfaction with the school buildings. Moreover, the POE result represents a notable pragmatic advancement to knowledge that will influence the contractor's knowledge and understanding of client satisfaction, and where to improve upon these.
\end{abstract}

Keywords: building services; construction; POE; refurbishment; schools; soft landings

\section{Introduction}

The post-handover stage for construction projects is the most neglected stage of construction [1]. This is because the handover process has not been revisited or modified drastically over recent years [2]. After project completion, there will be little to no effort made by the contractors or designers involved in the project, nor will they provide their insights to the end-users at the handover or post-occupancy stages [1]. As there has been no framework model introduced to ensure a collaborative and successful handover process between end parties, the inaccuracies and inconsistencies in the handover documentation have increased [3,4]. With the operational phase representing as much as 80 percent of the total cost of ownership for large commercial buildings, how as-built information is 
delivered to the end-users can greatly affect the owner's interests, which could consequently reduce the cost of ownership over time [5].

'Soft Landings' is described by the Building Services Research and Information Association (BSRIA) as: "A building delivery process which runs through the project, from inception to completion and beyond [6]". The process includes a smooth three-year handover to the building occupiers and post occupancy evaluation (POE) [7,8]. Using Soft Landings, the client's needs and requirements are clearly identified and guidelines are provided for the operatives to follow, thus ensuring smooth operation. In addition, outstanding issues obtained from POE feedback can be taken into account to prevent the same issues from repeating in future projects [6].

POE is a systematic process that is aided by research, exploring human needs, building performance, and facilities management (FM) $[9,10]$. POE methodologies have been widely applied to commercial and residential buildings, such as hospitals and nursing homes [2]. POE is also an invaluable tool to decide if construction projects have addressed end-users' needs, which include work performance, productivity and occupant performance [11]. Using questionnaires and interviews directed towards end-users, the POE process can also be undertaken for educational facilities. This will lead to a prompt facility evaluation, indicating positive issues as well as the negatives that impact the performance of the facility [12].

There is evidence that a strong correlation exists between the indoor environmental quality of the educational facilities and the performance of young students and teachers [13]. POE has been underused throughout the production and maintenance of secondary schools, which can contribute to health implications such as depression, anxiety and underperformance for staff and students [2]. Despite being able to rectify building errors and ensure end-user satisfaction, there is no legal provision for implementing the usage of POE [14]. This is a major concern as there is continuous pressure from the government and regulations on reducing educational expenditure. Through the use of POE, schools across the UK can achieve cost savings, which could be used to enhance the day-to-day life of facility inhabitants [11].

The UK Government recently announced the provision of $£ 560$ million to help repair deteriorating schools [15]. A rebuilding programme of 50 schools over a period of 10 years will begin in year 2020/21, and this will be aided with $£ 1$ billion funding [16]. Notwithstanding this initiative, it is common practice for builders and designers to, upon completion of a building project, move on to the next development without considering how the completed building performs in use or fine-tuning the building for better performance [1]. Therefore, this research aims to provide meaningful insights into building users' perceptions of the internal environmental conditions of refurbished educational facilities. In realising this aim, concomitant objectives are to: (1) augment building user satisfaction with the building they occupy post construction (because inadequate learning environments can affect the wellbeing of both students and teachers that occupy the facility); and (2) increasing client satisfaction with the contractor's works to secure future contracts for other new works; and (3) as a result of achieving point (2), mitigate the risk of developing adversarial relationships developing between clients and contractors on future projects.

\section{POE Process}

The definition of POE has evolved over time since its initial introduction over 50 years ago [17]. According to Preiser [18], POE allows "facility managers to identify and evaluate critical aspects of building performance systematically" and it can be categorised into three headings: indicative (involving quick, structured interviews and inspections), investigative (operating the use of interviews and survey questionnaires), and diagnostic (gathering sophisticated data over a period of months or years, gaining an insight of a wide range of performance evaluation aspects). Hassanain et al. [19] considers that POE can be categorised into two sections: technical performance and functional performance. Table 1 displays the differences between the two categories [20]. 
Table 1. Differences between technical and functional performance.

Technical Performance: $\quad$ Description $\quad$ References $\quad$ Functional Performance

Thermal comfort can be considered as,

"That condition of mind which expresses satisfaction with the thermal environment and is assessed by subjective evaluation".

Visual comfort in schools enhances not only health and wellbeing, but also satisfaction and therefore learning and visual performance.

Fire safety can be considered as, "Simply following the prescriptive code

Fire safety

Indoor air quality requirements to those that are based on fire safety analysis to obtain the required level of fire safety for the occupants". Indoor air quality has gained attention for improving the health, comfort, and wellbeing of building occupants as poor indoor air quality can be harmful to children, young adults and those suffering chronic respiratory and/or cardiovascular diseases.

Investigations on students and adults have found that children are more impaired than adults by background sounds in both speech perception and listening comprehension.
References

Philips [24] states that, "The physical

structure of a classroom is a critical variable

in affecting student morale and learning".

Allowing students to create an environment

can encourage their willingness to engage and interact more in lessons.

This includes focusing on the cost of

operating a facility, maintenance,

replacement and restoring assets within the

facilities. Ensuring the building is

functioning according to the specified operable condition.

A recent study conducted by Chang and Jaisook [24] showed that the aesthetic value has an impact on students creative and innovative behaviour.

Operational/maintenance management include functions that enable to transform input. This includes capital, energy,

$[21,22,29] \quad$ Operational management technology people and namely goods and services. Can also cover user support in order to provide quality services to enhance end-user satisfaction.

This includes providing completeness and adequacy of facilities alongside servicing and equipment.

Amenity 
On the contrary, Cooper [33] described POE as having at least three separate components that interlink (Figure 1). Extant literature illustrates that POE developments have occurred iteratively over time but its inherent objectives remain the same [34]. A common focus is to achieve end-user satisfaction or optimise energy saving [13]. In order to guarantee POE success, it is essential that the end-users, project managers, and stakeholders work in a collaborative manner. Otherwise, the benefits of POE will not become apparent nor come of much significance. The feedback techniques involved in POE, which can be used in different facilities, are plentiful. Bordass and Leaman [35] grouped them into five categories-refer to Table 2.

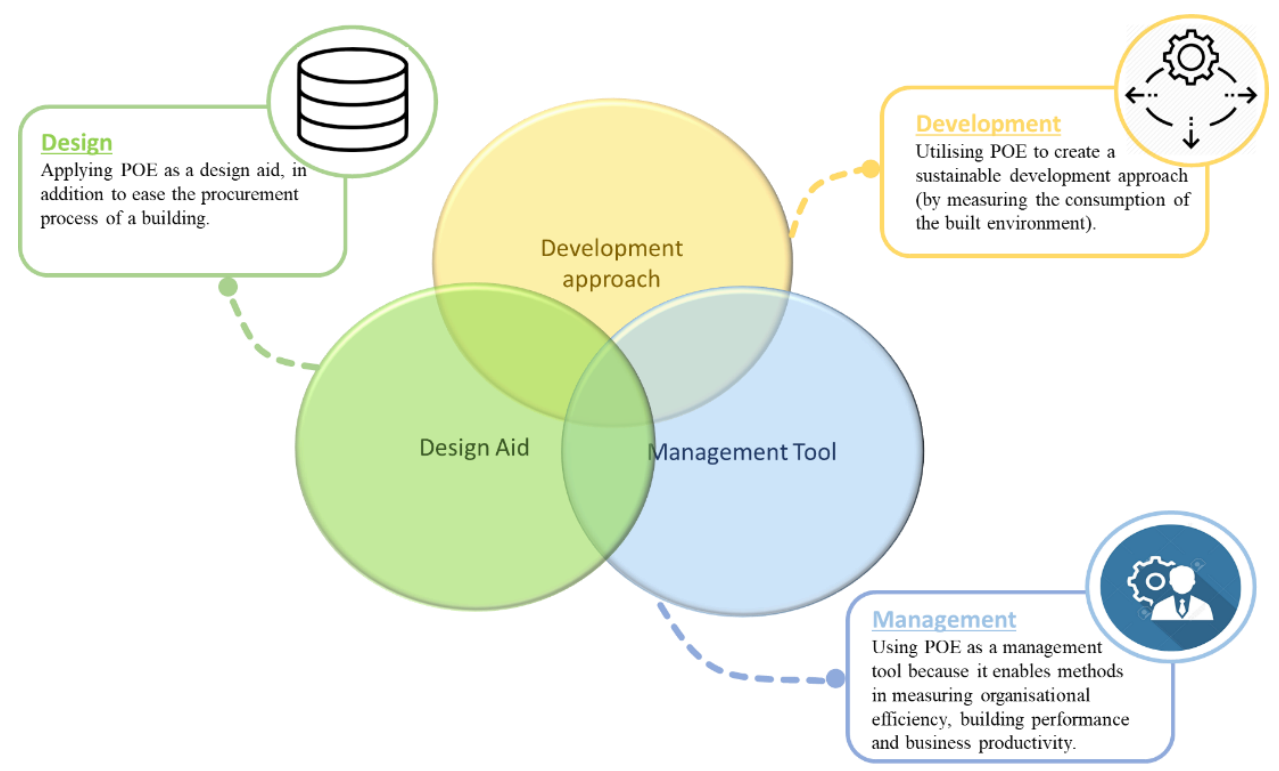

Figure 1. Applications of POE.

Table 2. POE feedback techniques.

\begin{tabular}{|c|c|c|}
\hline POE Feedback Techniques & Description & References \\
\hline Satisfaction Surveys & $\begin{array}{l}\text { Surveys are used to access the end-users' view of the functional and technical } \\
\text { performances of the facilities. Examples include utilising the BUS occupant } \\
\text { survey (UK), Overall Liking Scores and CIC design quality indicators. }\end{array}$ & {$[8,36]$} \\
\hline Discussion & $\begin{array}{c}\text { Discussion techniques involve organising interviews, brainstorming sessions } \\
\text { and workshops with end-users. This method is conducted mainly in order to } \\
\text { obtain an initial perception of the end-users of the building, in order to } \\
\text { develop the user satisfaction survey. }\end{array}$ & [12] \\
\hline Process & $\begin{array}{l}\text { Techniques are applied to the procurement process in order to integrate the } \\
\text { feedback in a logical manner. This can be achieved by the Building Research } \\
\text { Establishment checklist or through soft landings. }\end{array}$ & [37] \\
\hline Packages & $\begin{array}{l}\text { Examples include PROBE which incorporates qualitative and quantitative } \\
\text { data for surveys, interviews and walkthroughs. Likewise, AMA work ware } \\
\text { packages can be used which involves using an occupant survey. }\end{array}$ & {$[2,35]$} \\
\hline Audit & $\begin{array}{l}\text { Qualitative technical assessments are applied such as the CIBSE TM22 } \\
\text { energy assessment and reporting methodology. }\end{array}$ & [37] \\
\hline
\end{tabular}

A study published by Li et al. [38] shows how many POE studies were conducted on different building types. Some of these building types include: commercial, educational (nursery, primary, secondary), residential (houses, apartments, flats), and transport (railway and airport terminal) buildings. The purpose of conducting POE varies, dependent on the building type [24]. POEs for educational facilities tend to focus primarily on the efficiency of teaching activities; on the contrary, POEs for office buildings tend to involve investigating occupants' comfort and productivity [38]. The results obtained from this 
research showed that out of the 146 POE projects studied, only 18 (12.33\%) were related to educational facilities. This is worrying as there are over 32,000 schools in the UK alone [39] and, although nursery, primary and secondary schools have the same objective (educating pupils as they mature), the characteristics, structures, layouts, and specifications of their buildings differ tremendously.

\section{Methodology}

The overreaching epistemology adopted a mixed philosophical approach applying interpretivism and postpositivism [40]. Interpretavism was used to examine extant literature and identify the factors and variables that impact upon the phenomena under investigation. Interpretavism has been used widely in POE literature-for example, Roberts et al. [20] and Schweber [41] used this philosophical approach to investigate construction research, digital construction and POE. Postpositivism was used to capture the axiological perceptions of survey participants - both primary qualitive and quantitative data were collated using a questionnaire data collection instrument [42]. Empirical analysis of questionnaire data is ubiquitous within cotemporary construction management literature. Specifically, this approach has been used to: assess the policy provisions and institutional behavioural factors influencing rail infrastructure financing in developing countries [43]; conduct gap theory based post-occupancy evaluation (GTbPOE) of dormitory building performance [44,45]; and evaluate the challenges confronting smart city development in developing countries [46]. The research was also couched within inductive reasoning and a multiple case study strategy to generate new insight and theory into school renovations and refurbishments cf. [47]. The lead researcher was employed as a quantity surveyor within the main contractor undertaking the refurbishment works and hence, participant action research was also employed cf. [48]. Collectively, this body of knowledge underscores the appropriateness of the proposed epistemological design developed for this current research.

\subsection{Case Studies}

Three secondary schools based in the west Midlands, UK were used as case studies where teachers, caretakers, and teaching assistants formed the population of participants; these individuals were deemed to have an intimate knowledge of the classroom environment and were selected using non-probability purposive sampling cf. [49]. The schools were circa 20 years old and due for major refurbishment works hence, the current contract. Each Head of School was contacted via email to seek informed consent to participate in the research and assured that the research being conducted was in strict confidence and that no personal data would be divulged or disseminated to any third party willingly cf. [50]. As entry criteria, participants were required to have at least one-year service in the school to ensure that they were familiar with the works reviewed. The value of the works was over $£ 100$ million and the works were part of a repair and maintenance (R\&M) contract over a 20 year period. For this research, the works were those mainly on lighting, heating and air conditioning (ventilation) as these were the areas that had attracted the most challenging comments historically from the school staff. The contractor was keen to improve client satisfaction with these areas but first needed to understand more about the issues involved.

\subsection{Questionnaire Surveys}

A questionnaire survey was adopted for this research as it offers substantial benefits over alternative data collection instruments (e.g., focus groups and interviews) such as: speed and ease of administration; low cost; and potentially greater coverage of a population [51]. They are considered to be a key component of any building performance [52]. Sanni-Anibire et al. [53] considers that in regard to POE, questionnaires play the most significant role in determining whether or not the physical measurements, specifications and technicalities of the facility leads to end-user satisfaction. The survey produced for this research addresses a wide range of elements and performance qualities. These contribute to the overall performance satisfaction for the occupier of the facility. In order for the 
participants to understand the purpose of the survey, the questions were presented in a short and simple manner.

A mixed methods questionnaire data collection instrument developed consisted of two sections. Section one contained closed ended questions using a Likert scale of 1 to $5(1=$ unsatisfied and $5=$ very satisfied $)$ for the three areas under investigation, viz., lighting, heating and air conditioning/ventilation. A five-point scale was adopted to allow respondents to add a neutral response if they wished vis-à-vis forcing either a positive or negative response (as would be the case with a six-point scale). The overarching ambition was to determine how satisfied participants were with these building services and if satisfied, whether they were significantly satisfied at the $p=0.05$ confidence level. Such work could also determine the most important factors and variables in hierarchal order. Section two then posed open response questions for participants to provide further elucidation upon the rationale for their choices selected in section one. Such qualitative discourse was invaluable in unveiling further insightful explanations and identifying areas for future improvement and research. Approximately 180 staff were employed at the three schools (an exact figure was difficult to determine due to peripatetic staff employed periodically) and all were invited to complete the survey. A total of 45 responses were returned, representing a $25 \%$ response rate-this modest figure was slightly hindered by the COVID-19 global pandemic because many teachers were either furloughed and/or working from home at the time of data collection. Excessive staff workloads to create on-line teaching materials also hindered achieving a higher response rate.

\section{Data Analysis}

The study used Cronbach's Alpha as a reliability measure to assess the average inter-item covariance within the scale (internal consistency) used in the study instrument. Cronbach's Alpha is the most common reliability estimate in research specifically when examining issues related to scale reliability. The internal consistency analysis of the overall construct (all the indicators combined) and the sub-constructs received high reliability coefficient (Cronbach's Alpha). Davidoff et al. [54] and Debrah et al. [55] used the following indicators to interpret Cronbach Alpha coefficient values in surveys: 0.6-adequate/acceptable/marginal; 0.7-reasonable/preferable; 0.8-desirable/good; and 0.9-excellent. According to Tavakol and Dennick [56], any Cronbach coefficient value of 0.7 or above is considered good in research. The internal consistencies of the responses from the research instrument were high and considered excellent, as shown in Table 3.

Table 3. Reliability and validity statistics.

\begin{tabular}{ccc}
\hline & No. of Items & Cronbach's Alpha \\
\hline All & 14 & 0.987 \\
Lighting & 5 & 0.967 \\
Heating & 3 & 0.961 \\
Air Conditioning and Ventilation & 6 & 0.969 \\
\hline
\end{tabular}

\subsection{Determining Respondents' Level of Satisfaction}

The study used mean scores (mean ranking) and test statistics (one-sample-one tailed) to measure the satisfaction level of the respondents. The mean scores were utilized to rate the indicators of the three focuses in the study: lighting, heating, and air conditioning and ventilation based on the Likert scale. The mean scores were used in ranking the level of respondents' satisfaction (descending order). The test statistics according to Ahadzie et al. $[57,58]$ sought to measure whether the observed mean score equals the hypothesized mean (postulated). The hypothesized mean (or test statistic) was set to 3.5 as this is a useful benchmark to ensure that participants are satisfied; albeit some authors set this criteria higher at $4 \mathrm{cf}$. [59]. As a result, the null hypothesis states that between the observed mean and the hypothesized mean there is no statistical difference. 
The mean scores for respondents' satisfaction with the natural day lighting within the building, the quality of the artificial lighting in the building and the luminance within the room were respectively $3.89(\mathrm{SD}=0.959), 3.84(\mathrm{SD}=0.878)$, and $3.78(\mathrm{SD}=0.795)$. These were ranked from first to third among the indicators of lighting. These indicators were statistically significant, $t$-values were respectively $2.721,2.632$, and $2.345>$ critical value of 1.680 ( $p$-values $<0.05)$. The question on how respondents were satisfied with the positioning of the lighting objects within the building was scored 3.58 (ranked fourth), indicating that the respondents were averagely satisfied. However, the test statistics showed no significant satisfaction, $t$-value $0.643<$ critical value of 1.680 . The respondents were not averagely satisfied with the ability to adjust the lighting in their teaching rooms: mean score of 2.98 ( $\mathrm{SD}=1.033$ ); $t$-value of $-3.390<1.680$ (Table 4). The result showed that their level of satisfaction of the overall temperature of the building without heating was averagely neutral, and they were neutral with the positioning of the heating equipment (e.g., radiators) around the school and the amount of controllability they have in altering the heating within the building/classroom. These indicators under heating facility were statistically not significant: $t$-values below the critical value of 1.680 ( $p$-values $>0.05$ ).

Table 4. Mean (SD), mean rank, and test statistics ( $t$-value $=3.5)$.

\begin{tabular}{|c|c|c|c|c|c|c|}
\hline & Mean & Std. Dev. & Rank & $t$-Value & Critical Value & $p$-Value \\
\hline Lighting & - & & & & & \\
\hline $\begin{array}{l}\text { How satisfied are you with the natural day } \\
\text { lighting within the building? }\end{array}$ & 3.89 & 0.959 & 1 & 2.721 & 1.680 & 0.005 \\
\hline $\begin{array}{l}\text { How satisfied are you with the quality of the } \\
\text { artificial lighting in the building? }\end{array}$ & 3.84 & 0.878 & 2 & 2.632 & 1.680 & 0.006 \\
\hline $\begin{array}{l}\text { How satisfied are you with the luminance } \\
\text { within the room? }\end{array}$ & 3.78 & 0.795 & 3 & 2.345 & 1.680 & 0.012 \\
\hline $\begin{array}{l}\text { Are you satisfied with the ability to adjust the } \\
\text { lighting in your teaching rooms? }\end{array}$ & 2.98 & 1.033 & 5 & -3.390 & 1.680 & 0.999 \\
\hline $\begin{array}{l}\text { How satisfied are you with the positioning of } \\
\text { the lighting objects within the building? }\end{array}$ & 3.58 & 0.812 & 4 & 0.643 & 1.680 & 0.262 \\
\hline Overall Score & 3.61 & 0.846 & & 0.899 & 1.680 & 0.187 \\
\hline Heating & - & & & & & \\
\hline $\begin{array}{l}\text { How satisfied are you with the overall } \\
\text { temperature of the building without heating? }\end{array}$ & 2.82 & 1.072 & 2 & -4.241 & 1.680 & 1.000 \\
\hline $\begin{array}{l}\text { Are you satisfied with the positioning of the } \\
\text { heating equipment (e.g., radiators) around } \\
\text { the school? }\end{array}$ & 3.04 & 0.976 & 1 & -3.131 & 1.680 & 0.999 \\
\hline $\begin{array}{l}\text { Are you satisfied with the amount of } \\
\text { controllability you have in altering the } \\
\text { heating within the building/classroom? }\end{array}$ & 2.78 & 1.146 & 3 & -4.228 & 1.680 & 1.000 \\
\hline Overall Score & 2.88 & 1.028 & & -4.037 & 1.680 & 1.000 \\
\hline Air Conditioning and Ventilation & - & & & & & \\
\hline $\begin{array}{l}\text { How satisfied are you with the indoor air } \\
\text { quality of the building? }\end{array}$ & 3.42 & 0.839 & 1 & -3.630 & 1.680 & 1.000 \\
\hline $\begin{array}{l}\text { Are you satisfied with the natural ventilation } \\
\text { around the building? }\end{array}$ & 3.22 & 0.704 & 2 & -5.854 & 1.680 & 1.000 \\
\hline $\begin{array}{l}\text { Are you satisfied with the mechanical } \\
\text { ventilation around the building? }\end{array}$ & 3.22 & 0.704 & 2 & -3.821 & 1.680 & 1.000 \\
\hline $\begin{array}{l}\text { How satisfied are you with the positioning of } \\
\text { the air conditioning in the classroom? }\end{array}$ & 2.98 & 0.965 & 5 & -2.649 & 1.680 & 0.994 \\
\hline $\begin{array}{l}\text { Are you satisfied with the range of } \\
\text { temperatures the air conditioning provides? }\end{array}$ & 2.98 & 0.917 & 4 & -2.649 & 1.680 & 0.994 \\
\hline $\begin{array}{l}\text { How satisfied are you with the controllability } \\
\text { of the air conditioning in the building? }\end{array}$ & 2.6 & 1.031 & 6 & -0.622 & 1.680 & 0.731 \\
\hline Overall Score & 3.07 & 0.808 & & -3.565 & 1.680 & 1.000 \\
\hline
\end{tabular}


Items under "air conditioning and ventilation" were averagely scored as neutral. From the results, the first-ranked, showing the most satisfied among the indicators of air conditioning, was the indoor quality of the building, followed by natural ventilation around the building and then mechanical ventilation around the building. The mean scores for these indicators were $3.42(\mathrm{SD}=0.839), 3.22(\mathrm{SD}=0.704)$, and $3.22(\mathrm{SD}=0.704)$ respectively. The remaining indicators were averagely between mean scores of 2.60 to 2.98 (neutral). Generally, all the indicators were statistically not significant: $t$-values $<1.680$ ( $p$-values > 0.05); thus, the mean scores, below the hypothesized mean of 3.5, indicate that the respondents were not satisfied about the air conditioning and ventilation services. Interestingly standard deviations recorded were relatively high and indicated some variability in responses recorded - such variability was indicative of individual perceptions that are explored in further detail in the discussion section.

\subsection{Measure of Variations in Respondents' Level of Satisfaction (Kruskal-Wallis Test)}

The variations in respondents' level of satisfaction were measured using the nonparametric test known as Kruskal-Wallis. The Kruskal-Wallis test evaluates the differences between three or more independently sampled groups on a single, non-normally distributed continuous variable [60] as in this study. According to McKight and Najab [61], the Kruskal-Wallis test, which is an extension of the two-group Mann-Whitney U (Wilcoxon rank) test, is more suitable for non-normally distributed data (e.g., ordinal or rank data). This model was chosen based on the non-normal distribution of the data and that there were three groups for comparison: school 1, school 2, and school 3. It measured statistical differences that existed in the respondents' scores of their level of satisfaction to each of the indicators under each focus of the study: lighting, heating, and air conditioning and ventilation. The postulation of the model was that there was no significant difference in the level of satisfaction, and the research hypothesis was that there was at least significant difference between two of the groups in their level of satisfaction.

The results (Table 5) revealed that there were no significant differences in the levels of satisfaction between the three schools. The chi-square values of the Kruskal-Wallis test were less than 5.991 - critical value ( $p$-values $>0.05$ ). This observation suggested that all the respondents from the three groups had the same level of satisfaction of all the measurement indicators. There were no significant differences among the respondents from the schools.

Table 5. Kruskal-Wallis Test statistics ${ }^{\mathrm{a}, \mathrm{b}}$ of the three schools sampled.

\begin{tabular}{|c|c|c|c|c|c|}
\hline & Chi-Square & df & Critical Values & $p$-Value & Level of Sig. \\
\hline \multicolumn{6}{|l|}{ Lighting } \\
\hline $\begin{array}{l}\text { How satisfied are you with the natural day lighting within } \\
\text { the building? }\end{array}$ & 0.701 & 2 & 5.991 & 0.704 & NS \\
\hline $\begin{array}{l}\text { How satisfied are you with the quality of the artificial } \\
\text { lighting in the building? }\end{array}$ & 0.095 & 2 & 5.991 & 0.953 & NS \\
\hline How satisfied are you with the luminance within the room? & 0.044 & 2 & 5.991 & 0.978 & NS \\
\hline $\begin{array}{l}\text { Are you satisfied with the ability to adjust the lighting in } \\
\text { your teaching rooms? }\end{array}$ & 2.141 & 2 & 5.991 & 0.343 & NS \\
\hline $\begin{array}{l}\text { How satisfied are you with the positioning of the lighting } \\
\text { objects within the building? }\end{array}$ & 0.513 & 2 & 5.991 & 0.774 & NS \\
\hline \multicolumn{6}{|l|}{ Heating } \\
\hline $\begin{array}{c}\text { How satisfied are you with the overall temperature of the } \\
\text { building without heating? }\end{array}$ & 2.352 & 2 & 5.991 & 0.308 & NS \\
\hline $\begin{array}{l}\text { Are you satisfied with the positioning of the heating } \\
\text { equipment (e.g., radiators) around the school? }\end{array}$ & 3.344 & 2 & 5.991 & 0.188 & NS \\
\hline $\begin{array}{l}\text { Are you satisfied with the amount of controllability you } \\
\text { have in altering the heating within the building/classroom? }\end{array}$ & 0.899 & 2 & 5.991 & 0.638 & NS \\
\hline
\end{tabular}


Table 5. Cont.

\begin{tabular}{|c|c|c|c|c|c|}
\hline & Chi-Square & df & Critical Values & $p$-Value & Level of Sig. \\
\hline \multicolumn{6}{|c|}{ Air Conditioning and Ventilation } \\
\hline $\begin{array}{l}\text { How satisfied are you with the positioning of the air } \\
\text { conditioning in the classroom? }\end{array}$ & 2.560 & 2 & 5.991 & 0.278 & NS \\
\hline $\begin{array}{l}\text { How satisfied are you with the controllability of the air } \\
\text { conditioning in the building? }\end{array}$ & 0.950 & 2 & 5.991 & 0.622 & NS \\
\hline $\begin{array}{l}\text { Are you satisfied with the range of temperatures the air } \\
\text { conditioning provides? }\end{array}$ & 3.343 & 2 & 5.991 & 0.188 & NS \\
\hline $\begin{array}{l}\text { Are you satisfied with the natural ventilation around } \\
\text { the building? }\end{array}$ & 2.850 & 2 & 5.991 & 0.240 & NS \\
\hline $\begin{array}{l}\text { Are you satisfied with the mechanical ventilation around } \\
\text { the building? }\end{array}$ & 2.850 & 2 & 5.991 & 0.240 & NS \\
\hline $\begin{array}{c}\text { How satisfied are you with the indoor air quality of } \\
\text { the building? }\end{array}$ & 0.800 & 2 & 5.991 & 0.670 & NS \\
\hline
\end{tabular}

NS—Not significant. a. Kruskal Wallis Test \& b. Grouping Variable: School.

\section{Discussion}

The foregoing statistical analysis results reveal that there were no significant differences between the three schools in terms of users' perceptions of heating, lighting, and air conditioning and ventilation following refurbishment works conducted. Hence, the three schools can be discussed en-masse for each of the three types of building services and overall, respondents were reasonably satisfied with their internal working environments but not to a significant level $(p=0.05)$ for most questions posed. To probe deeper into the reasons given by the respondents for their dissatisfaction with certain elements of the internal school environments, a manual content analysis of qualitative responses to section two of the questionnaire was undertaken.

\subsection{Lighting}

Overall, the survey participants indicated that the lighting within the building and individual classrooms was satisfactory although there was some dissatisfaction with the ability to adjust the lighting in their teaching rooms. The qualitative open response questions recorded 24 comments, which, after analysis, were found to be clustered into four thematic groupings (in order of the frequency $(f)$ of comments made): (1) the need for adjustable lighting ( $f=15$ or $62.5 \%)$; (2) occupants' comfort and health $(f=4$ or $16.67 \%)$; (3) satisfied with current provisions $(f=3$ or $12.50 \%)$; and (4) natural light preference ( $f=2$ or $8.33 \%$ ). Overwhelmingly, $62 \%$ of the comments recorded requested an ability to adjust lighting to suit activities within the classroom — such as dim lighting for presentations and bright lighting for artwork. Typical verbatim comments included: "Lighting is poor as there is no ability to turn certain ones off or dim the lights ... "; "Lighting within the building is fine, would be ideal if the lighting level could be adjusted in the classrooms"; and "Lights are sensor controlled therefore, they can not be adjusted. Would help if lighting could be dimmed/adjusted in the classrooms". Four participants experienced discomfort and health issues (e.g., "Feel like the lighting is giving me a headache as it is to bright") and perhaps these comments could also relate to the need to adjust lighting by occupants $[26,62]$. Only three participants explicitly expressed views that they were satisfied with the lighting arrangements and two stated that they preferred natural light and offered solutions to enable this, viz., "A greater use of natural light could have been made, sky lights on the upper floor". An ability to adjust lighting to ensure occupant comfort, health and well-being is well established within extant literature, for example: Kim et al. [63] examined interactive lighting systems in the workplace by reviewing energy and occupant perspectives; and more recently Mansor and Sheau-Ting [64] reviewed the criteria for occupant well-being using a qualitative study of Malaysian office buildings, where lighting was considered under the area of occupant health. Concurring with this earlier 
research [65], the present study suggests that to obtain optimum building user satisfaction, some element of controllable lighting is essential, particularly in teaching environments.

\subsection{Heating}

For heating, participants were averagely neutral and this finding was also reflected in the qualitative responses recorded. The twenty six comments recorded for this part were thematically grouped into four clusters: (1) the need for adjustable heating ( $f=18$ or $69.23 \%$ ); (2) occupant comfort and health $(f=4$ or $15.38 \%)$; (3) access to heating systems $(f=2$ or $7.69 \%)$; and (4) satisfied with current provisions ( $f=2$ or $7.69 \%)$. Akin to lighting, the occupants overwhelmingly requested greater controllability of heating in the school and classrooms, viz., "I have no control over the temperature in school facility and it is either too warm or cold"; and "Being on the top floor of the building under floor heating is available however the heating can range from being either to hot or cold. We have no direct control of the heating of the classrooms within the building". Interestingly, the global pandemic (where the UK has experienced some of the highest death rates per capita cf. [66]) also played an important part in securing occupant comfort, as one participant noted: "No control of heating, just the ability to open windows. Due to the precautions (such as opening windows to allow fresh air flow) that need to be put into place because of the pandemic, the classrooms are too cold, usually are fine". Occupants' comfort and health again ranked second in the highest number of attributable comments raised, viz., "There is no option for changing temperature underfloor heating is ineffective, vastly varying temperatures across the school" and "The heating takes a long time too [to] feel a noticeable difference". Only two participants expressed a level of satisfaction while two others raised concerns about access to heating systems, viz., "Some of the radiators are behind fixed units which is unreachable". The notion of questionable thermal comfort has been raised by authors such as Hawila et al. [67] whilst Wang et al. [68] raised the need for occupant controllability of thermal heating within buildings to ensure thermal comfort.

\subsection{Air Conditioning and Ventilation}

Perceptions of air conditioning and ventilation were perhaps the most variable among the sample respondents who gave averagely neutral responses. The 27 qualitative comments given on this part were thematically grouped into four categories: (1) concerns about an inadequate design ( $f=9$ or $33.33 \%)$; (2) the need for adjustable air conditioning and ventilation ( $f=6$ or $22.22 \%$ ); (3) lack of natural ventilation $(f=6$ or $22.22 \%$ ); and (4) satisfied with current provisions ( $f=6$ or $22.22 \%$ ). More than lighting or heating, this category experienced the highest level of variability in responses and disagreement, less emphasis on controllability, but far more concerns about a perceived inappropriate design. For example, sample participant comments included: "This type of building is designed for office use not ideal for educational needs" and "Underfloor heating zoning not very efficient. Inability to alter the heating in the classrooms". Closely related to design was the need for natural ventilation (perhaps a need accentuated by the global pandemic?). Participants stated, for example, "Sufficient number of windows around the school to open for ventilation"; "New classrooms that have been added have very little ventilation and 1 of them have no windows"; and "It is difficult to ventilate some rooms due to windows having locks on them". Overall, the prevailing negative discourse creates a sense of a hermitically sealed and claustrophobic indoor environment that prevents occupants from adjusting or controlling air flow (natural or mechanical). This was perhaps exhibited best by the comments: "The heating is controlled by an outside source, therefore there is little to no control". This comment suggests that the drive to automate the indoor environment works on a one-shoe-fits-all basis and yet, people differ in body mass index, anthropometric characteristics, behavioural patterns, etc. cf. [69] and so react very differently to the internal environment particularly in terms of thermal comfort and/or the need for ventilation to regulate this. In stark contrast, several responses claimed the complete opposite to the larger body of comments recorded, viz., "Air conditioning units work well and ventilate 
well" and "Ventilation is well managed by site staff" — such polar opposite responses raise further lines of enquiry.

\subsection{Considerations, Implications, and Limitations}

The prevailing body of knowledge points towards advanced digital technologies embodied within the concept of Industry $4.0 \mathrm{cf}$. [70,71] coalescing to provide fully automated smart buildings and infrastructure cf. [59]. Yet, the findings of this current study reveal that occupants of school buildings within the UK's temperate climate resent the trend for hermetically sealed and computer controlled internal environments cf. [72] in favour for a more localised manual control over the building services. This could be due to a disregard for current trends to automatically control the internal environment for cost and environmental purposes but equally likely, it may be because different users have different physiological needs [69]. Moreover, different areas of the building may have very different educational needs [73,74] — for example, an art room requires more natural light whilst a sports hall requires more ventilation. Such knowledge acquired from this present study will help to mitigate the risk of developing adversarial relationships developing between clients and contractors on future building projects by better meeting clients' needs and requirements. The key to achieving this ambition will be to ensure that a feedback loop is built into the project procurement process to facilitate the development of a knowledge empowered organization that learns from past projects to inform future practice and developments.

Although beyond the scope of this present paper, it was also apparent that occupants were semi-divorced from the design stage of the contract and perhaps greater involvement could have allayed the concerns raised post occupancy. That said, such works come under the control of the local authority jurisdiction and budgeted costs for refurbishment may have been a prohibitive factor-perhaps the idiom 'cut your cloth' prevailed over decisions regarding available finances for these three projects. Further work is required to explore this phenomenon in greater detail by conducting cost-benefit analysis between greater investment and higher occupant satisfaction. Such work could establish the intersect between the point at which further financial investment produces minimal increases in occupant satisfaction.

Admittedly, there are limitations of this work, including: a comparatively small sample size; the limited number of environmental factors considered; the geographical positioning of the case studies (i.e., West Midlands conurbation, UK); and the fact that the work presented adopted a case study approach, even though it covered multiple cases. Such limitations invariably restrict the inference and wider applicability and generalisation of the findings but also raise some interesting lines of future research investigation. Such work could include the aforementioned cost-benefit analysis and cover a wider body of R\&M and refurbishment projects.

\section{Conclusions}

POE affords an invaluable opportunity for members of the design and construction team to review and assess the performance of a building from the client's perspective. Lessons learnt from this feedback-loop process should be utilised to improve the performance of future designs but extant literature suggests that this is rarely the case cf. [75]. Research also demonstrates that comprehensive POE conducted on schools has received scant academic attention and often occupants are semi-divorced from the design process as ultimately the local authority acts as a client and budget holder. Such a procurement arrangement may be leading to a less than desirable internal environment for school staff who are ostensibly given a finished product vis-à-vis actively engaged in its development or adequately experienced enough to inform the design and construction process. Overall, for the three schools reviewed, a general sense of satisfaction was observed (despite the negative comments raised) but that with more exhaustive thought and planning at the design stage, a greater sense of occupant satisfaction could have been secured. This has 
obvious financial ramifications for the contractor winning future tenders and securing organisational profitability moving forwards-often future customers simply switch to sourcing alternative suppliers if they become dissatisfied [76]. This potential loss of future business is difficult to quantify but may be substantial.

Strong resistance to automated systems of internal environmental control were also observed and reported upon, which runs contrary to the prevailing academic enthusiasm for 'all things digital' within contemporary construction and civil engineering management literature. Occupants wanted greater control over the internal environment to reflect the various activities and tasks performed on a daily basis as well as adjust the personal preference needs and/or in some instances, the feeling of ill-health. This was apparent for all three areas analysed, viz., heating, lighting, and air conditioning and ventilation. This raises some interesting observations about how far humanity should embrace the digital revolution to create a fully-automated cyber physical system. This (in many ways) rhetorical question concurs with the earlier work of Edwards et al. [77] who stated that "mankind must hence assert domic and not become its slave".

Several limitations of the work were also apparent. For example, the small sample size, the lack of generalisation associated with case study research and the number of factors considered. That said, the work provides a benchmark upon which future work could be based to improve the internal environment for schools. By improving the experience of teaching and learning in the classroom, concomitant improvements in student satisfaction and attainment are envisaged, augmenting future business prospects of all stakeholders involved in the design and construction works.

Author Contributions: Conceptualization, H.A. and D.J.E.; methodology, H.A., D.J.E. and C.R.; validation, H.A. and D.J.E., J.H.K.L. and W.D.T.; formal analysis, H.A., D.J.E., C.D., W.D.T. and D.-G.O.-M.; investigation, H.A. and D.J.E.; data curation, H.A. and D.J.E.; writing-original draft preparation, H.A., D.J.E. and C.R.; writing-review and editing, H.A., D.J.E., C.R., J.H.K.L. and W.D.T.; supervision, D.J.E.; project administration, H.A. and D.J.E. All authors have read and agreed to the published version of the manuscript.

Funding: This research received no external funding.

Institutional Review Board Statement: The study was conducted according to an ethical protocol that was approved by the Computing, Engineering and the Built Environment Faculty Academic Ethics Committee) of Birmingham city University (Edwards /\#7741 / sub1 /Mod /2020 /Sep /CEBE FAEC—BNV6200 ACM Version D.J. Edwards- 13th October 2020).

Informed Consent Statement: Informed consent was obtained from all subjects involved in the study.

Data Availability Statement: Anonymized data is available from the corresponding author upon written request and subject to review.

Conflicts of Interest: The authors declare no conflict of interest.

\section{References}

1. Way, M.; Bordass, B. Making feedback and post-occupancy evaluation routine 2: Soft landings-involving design and building teams in improving performance. Build. Res. Inf. 2005, 33, 353-360. [CrossRef]

2. Riley, M.; Kokkarinen, N.; Pitt, M. Assessing post occupancy evaluation in higher education facilities. J. Facil. Manag. 2010, 8, 202-213. [CrossRef]

3. Alborz, N.; Berardi, U. A post occupancy evaluation framework for LEED certified U.S. higher education residence halls. Procedia Eng. 2015, 118, 19-27. [CrossRef]

4. Chan, D.W.; Kumaraswamy, M.M. A comparative study of causes of time overruns in Hong Kong construction projects. Int. J. Proj. Manag. 1997, 15, 55-63. [CrossRef]

5. Zhu, L.; Shan, M.; Xu, Z. Critical review of building handover-related research in construction and facility management journals. Eng. Constr. Archit. Manag. 2019, 28, 154-173. [CrossRef]

6. Bsria. Soft Landings Framework or Guides, Building Design Process UK BSRIA (2020). Available online: https://www.bsria. $\mathrm{com} / \mathrm{uk} /$ consultancy/project-improvement/soft-landings/ (accessed on 1 March 2021).

7. Chater, M. Soft Landings for Public Sector. Available online: https://www.local.gov.uk/soft-landings-public-sector (accessed on 14 April 2021). 
8. Tuohy, P.G.; Murphy, G.B. Closing the gap in building performance: Learning from BIM benchmark industries. Arch. Sci. Rev. 2014, 58, 47-56. [CrossRef]

9. Forcada, N.; Macarulla, M.; Fuertes, A.; Casals, M.; Gangolells, M.; Roca, X. Influence of Building Type on Post-Handover Defects in Housing. J. Perform. Constr. Facil. 2012, 26, 433-440. [CrossRef]

10. Hassanain, M.A.; Mudhei, A.A. Post-occupancy evaluation of academic and research library facilities. Struct. Surv. 2006, 24, 230-239. [CrossRef]

11. Hassanain, M.A.; AlAmoudi, A.; Al-Hammad, A.-M.; Abdallah, A. Barriers to the implementation of POE practices in the Saudi Arabian building industry. Arch. Eng. Des. Manag. 2020, 16, 150-165. [CrossRef]

12. Hassanain, M.A.; Iftikhar, A. Framework model for post-occupancy evaluation of school facilities. Struct. Surv. 2015, 33, 322-336. [CrossRef]

13. Hameen, E.C.; Ken-Opurum, B.; Son, Y.J. Protocol for Post Occupancy Evaluation in Schools to Improve Indoor Environmental Quality and Energy Efficiency. Sustainability 2020, 12, 3712. [CrossRef]

14. SCI-Network. An Insight into Post Occupancy Evaluation; Technical Report; SCI-Network: Freiburg im Breisgau, BadenWürttemberg, Germany, 2012; p. 19. Available online: https://sci-network.eu/fileadmin/templates/sci-network/files/ Resource_Centre/Reports/SCIN_POE_final_report_-_June_2012.pdf (accessed on 1 April 2021).

15. Morby, A. £1Bn Pledged For 50 New Schools Building Blitz. Construction Enquirer News. 2020. Available online: https: //www.constructionenquirer.com/2020/06/29/1bn-pledge-to-fast-track-50-school-projects/ (accessed on 14 April 2021).

16. Rodgers, E. Boris Johnson Announces $£ 1 B n$ School Rebuilding Programme $\backslash$ Public Sector Executive; Public Sector Executive: Manchester, UK, 2020; Available online: https:/ /www.publicsectorexecutive.com/articles/boris-johnson-announces-ps1bnschool-rebuilding-programme (accessed on 14 April 2021).

17. Göçer, Ö.; Hua, Y.; Göçer, K. Completing the missing link in building design process: Enhancing post-occupancy evaluation method for effective feedback for building performance. Build. Environ. 2015, 89, 14-27. [CrossRef]

18. Preiser, W.F. Post-occupancy evaluation: How to make buildings work better. Facilities 1995, 13, 19-28. [CrossRef]

19. Hassanain, M.A.; Mathar, H.; Aker, A. Post-occupancy evaluation of a university student cafeteria. Arch. Eng. Des. Manag. 2015, 12, 67-77. [CrossRef]

20. Roberts, C.; Edwards, D.J.; Hosseini, M.R.; Mateo-Garcia, M.; Owusu-Manu, D.-G. Post-occupancy evaluation: A review of literature. Eng. Constr. Arch. Manag. 2019, 26, 2084-2106. [CrossRef]

21. Lai, J.H.K.; Yik, F.W.H. Perceived Importance of the Quality of the Indoor Environment in Commercial Buildings. Indoor Built Environ. 2007, 16, 311-321. [CrossRef]

22. Lai, J.H.; Yik, F.W. Perception of importance and performance of the indoor environmental quality of high-rise residential buildings. Build. Environ. 2009, 44, 352-360. [CrossRef]

23. Wu, Z.; Li, N.; Wargocki, P.; Peng, J.; Li, J.; Cui, H. Adaptive thermal comfort in naturally ventilated dormitory buildings in Changsha, China. Energy Build. 2019, 186, 56-70. [CrossRef]

24. Philips, M. A Place for Learning: The Physical Environment of Classrooms. 2014. Available online: https://www.edutopia.org/ blog/the-physical-environment-of-classrooms-mark-phillips (accessed on 14 April 2021).

25. Gearhart, A.; Booth, D.T.; Sedivec, K.; Schauer, C. Use of Kendall's coefficient of concordance to assess agreement among observers of very high resolution imagery. Geocarto Int. 2013, 28, 517-526. [CrossRef]

26. Korsavi, S.S.; Zomorodian, Z.S.; Tahsildoost, M. Visual comfort assessment of daylit and sunlit areas: A longitudinal field survey in classrooms in Kashan, Iran. Energy Build. 2016, 128, 305-318. [CrossRef]

27. Hashim, A.E.; Aksah, H.; Said, S.Y. Functional Assessment through Post Occupancy Review on Refurbished Historical Public Building in Kuala Lumpur. Procedia Soc. Behav. Sci. 2012, 68, 330-340. [CrossRef]

28. Benichou, N.; Kashef, A.H.; Reid, I.; Hadjisophocleous, G.V.; Morinville, G.; Torvi, D.A. FIERAsystem: A Fire Risk Assessment Tool to Evaluate Fire Safety in Industrial Buildings and Large Spaces. J. Fire Prot. Eng. 2005, 15, 145-172. [CrossRef]

29. Cincinelli, A.; Martellini, T. Indoor Air Quality and Health. Int. J. Environ. Res. Public Health 2017, 14, 1286. [CrossRef] [PubMed]

30. Myeda, N.E.; Kamaruzzaman, S.N.; Pitt, M. Measuring the performance of office buildings maintenance management in Malaysia. J. Facil. Manag. 2011, 9, 181-199. [CrossRef]

31. Buratti, C.; Belloni, E.; Merli, F.; Ricciardi, P. A new index combining thermal, acoustic, and visual comfort of moderate environments in temperate climates. Build. Environ. 2018, 139, 27-37. [CrossRef]

32. Meir, I.A.; Garb, Y.; Jiao, D.; Cicelsky, A. Post-Occupancy Evaluation: An Inevitable Step Toward Sustainability. Adv. Build. Energy Res. 2009, 3, 189-219. [CrossRef]

33. Cooper, I. Post-occupancy evaluation-Where are you? Building Research and Information. Spec. Issue Post Occup. Eval. 2001, 29, 158-163.

34. Bengi, S.I.; Toprakl1, A.Y. The Perspective of Turkey in the Post Occupancy Evaluation Studies. Period. Polytech. Arch. 2020, 51, 83-91. [CrossRef]

35. Bordass, B.; Leaman, A. Making feedback and post-occupancy evaluation routine 1: A portfolio of feedback techniques. Build. Res. Inf. 2005, 33, 347-352. [CrossRef]

36. Pemsel, S.; Widén, K.; Hansson, B. Managing the needs of end-users in the design and delivery of construction projects. Facilities 2010, 28, 17-30. [CrossRef]

37. Hadjri, K.; Crozier, C. Post-occupancy evaluation: Purpose, benefits and barriers. Facilities 2009, 27, 21-33. [CrossRef] 
38. Li, P.; Froese, T.M.; Brager, G. Post-occupancy evaluation: State-of-the-art analysis and state-of-the-practice review. Build. Environ. 2018, 133, 187-202. [CrossRef]

39. Loannou, A. Key UK Education Statistics-BESA. 2020. Available online: https:/ /www.besa.org.uk/key-uk-education-statistics/\# $\sim\{\}:$ text=There $\% 20$ are $\% 20$ curently $\% 2032 \% 2 C 770 \% 20$ schools $\% 20$ in $\% 20$ the $\% 20 U K .$, Most $\% 20$ of $\% 20$ the $\% 20$ UK\%E2\%80\%99s $\% 20$ schools\%20are\%20in\%20England (accessed on 14 April 2021).

40. Akinlolu, M.; Haupt, T.C.; Edwards, D.J.; Simpeh, F. A bibliometric review of the status and emerging research trends in construction safety management technologies. Int. J. Constr. Manag. 2020. [CrossRef]

41. Schweber, L. Putting theory to work: The use of theory in construction research. Constr. Manag. Econ. 2016, 33, 840-860. [CrossRef]

42. Hesse-Biber, S. Qualitative Approaches to Mixed Methods Practice. Qual. Inq. 2010, 16, 455-468. [CrossRef]

43. Owusu-Manu, D.-G.; Edwards, D.; Ghansah, F.A.; Asiedu, R.O.; Tagoe, D.S.N.; Birch, T. Assessing the Policy Provisions and Institutional Behavioral Factors Influencing Rail Infrastructure Financing in Developing Countries. J. Infrastruct. Syst. 2021, 27, 05021004. [CrossRef]

44. Hou, H.; Lai, J.H.; Edwards, D. Gap theory based post-occupancy evaluation (GTbPOE) of dormitory building performance: A case study and a comparative analysis. Build. Environ. 2020, 185, 107312. [CrossRef] [PubMed]

45. Lai, J.H.K. Gap theory based analysis of user expectation and satisfaction: The case of a hostel building. Build. Environ. 2013, 69, 183-193. [CrossRef]

46. Aghimien, D.O.; Aigbavboa, C.; Edwards, D.J.; Mahamadu, A.-M.; Olomolaiye, P.; Nash, H.; Onyia, M. A fuzzy synthetic evaluation of the challenges of smart city development in developing countries. Smart Sustain. Built Environ. 2020. [CrossRef]

47. Edwards, D.J.; Love, P.E. A case study of machinery maintenance protocols and procedures within the UK utilities sector. Accid. Anal. Prev. 2016, 93, 319-329. [CrossRef] [PubMed]

48. Pärn, E.; Edwards, D. Conceptualising the FinDD API plug-in: A study of BIM-FM integration. Autom. Constr. 2017, 80, 11-21. [CrossRef]

49. Campbell, S.; Greenwood, M.; Prior, S.; Shearer, T.; Walkem, K.; Young, S.; Bywaters, D.; Walker, K. Purposive sampling: Complex or simple? Research case examples. J. Res. Nurs. 2020, 25, 652-661. [CrossRef]

50. Fisher, L.H.; Edwards, D.J.; Pärn, E.A.; Aigbavboa, C.O. Building design for people with dementia: A case study of a UK care home. Facilities 2018, 36, 349-368. [CrossRef]

51. Gilham, B. Developing a Questionnaire; Bloomsbury: London, UK, 2008; ISBN 9780826496317.

52. Nooraei, M.; Littlewood, J.; Evans, N. Feedback from Occupants in 'as Designed' Low-carbon Apartments, a Case Study in Swansea, UK. Energy Procedia 2013, 42, 446-455. [CrossRef]

53. Sanni-Anibire, M.O.; Hassanain, M.A.; Al-Hammad, A.-M. Post-Occupancy Evaluation of Housing Facilities: Overview and Summary of Methods. J. Perform. Constr. Facil. 2016, 30, 04016009. [CrossRef]

54. Davidoff, F.; Gordon, N.; Tarnow, E.; Endriss, K. A Question of Response Rate. Available online: https://www. councilscienceeditors.org/wpcontent/uploads/v25n1p025-026.pdf (accessed on 1 March 2021).

55. Debrah, C.; Owusu-Manu, D.-G.; Kissi, E.; Oduro-Ofori, E.; Edwards, D.J. Barriers to green cities development in developing countries: Evidence from Ghana. Smart Sustain. Built Environ. 2020. [CrossRef]

56. Tavakol, M.; Dennick, R. Making sense of Cronbach Alpha. Int. J. Med. Educ. 2011, 2, 53-55. [CrossRef] [PubMed]

57. Ahadzie, D.K.; Proverbs, D.G.; Olomolaiye, P.O. Model for Predicting the Performance of Project Managers at the Construction Phase of Mass House Building Projects. J. Constr. Eng. Manag. 2008, 134, 618-629. [CrossRef]

58. Ahadzie, D.; Proverbs, D.; Olomolaiye, P. Critical success criteria for mass house building projects in developing countries. Int. J. Proj. Manag. 2008, 26, 675-687. [CrossRef]

59. Ghansah, F.A.; Owusu-Manu, D.-G.; Ayarkwa, J.; Darko, A.; Edwards, D.J. Underlying indicators for measuring smartness of buildings in the construction industry. Smart Sustain. Built Environ. 2020. [CrossRef]

60. Kruskal, W.H.; Wallis, W.A. Use of ranks in one-criterion variance analysis. J. Am. Stat. Assoc. 1952, 47, 583-621. [CrossRef]

61. McKight, P.E.; Najab, J. Kruskal-Wallis Test. In The Corsini Encyclopedia of Psychology; Weiner, I.B., Craighead, W.E., Eds.; John Wiley \& Sons, Inc.: Hoboken, NJ, USA, 2010; p. corpsy0491, ISBN 978-0-470-47921-6.

62. Kralikova, R.; Wessely, E. Lighting Quality, Productivity and Human Health. In Proceedings of the 29th International DAAAM Symposium (DAAAM 2018), Zadar, Croatia, 24-27 October 2018; pp. 59-65.

63. Kim, A.A.; Wang, S.; McCunn, L.J. Building value proposition for interactive lighting systems in the workplace: Combining energy and occupant perspectives. J. Build. Eng. 2019, 24, 100752. [CrossRef]

64. Legendre, P. Coefficient of concordance. In Encyclopaedia of Research Design; Salkind, N.J., Ed.; SAGE Publications, Inc.: Los Angeles, CA, USA, 2010; Volume 1, p. 1776, ISBN 9781412961271.

65. Durak, A.; Olguntürk, N.C.; Yener, C.; Güvenç, D.; Gürçınar, Y. Impact of lighting arrangements and illuminances on different impressions of a room. Build. Environ. 2007, 42, 3476-3482. [CrossRef]

66. Anderson, R.M.; Hollingsworth, T.D.; Baggaley, R.F.; Maddren, R.; Vegvari, C. COVID-19 spread in the UK: The end of the beginning? Lancet 2020, 396, 587-590. [CrossRef]

67. Hawila, A.A.-W.; Merabtine, A.; Chemkhi, M.; Bennacer, R.; Troussier, N. An analysis of the impact of PMV-based thermal comfort control during heating period: A case study of highly glazed room. J. Build. Eng. 2018, 20, 353-366. [CrossRef]

68. Wang, H.; Olesen, B.W.; Kazanci, O.B. Using thermostats for indoor climate control in offices: The effect on thermal comfort and heating/cooling energy use. Energy Build. 2019, 188, 71-83. [CrossRef] 
69. Rupp, R.F.; Kim, J.; de Dear, R.; Ghisi, E. Associations of occupant demographics, thermal history and obesity variables with their thermal comfort in air-conditioned and mixed-mode ventilation office buildings. Build. Environ. 2018, 135, 1-9. [CrossRef]

70. Newman, C.; Edwards, D.; Martek, I.; Lai, J.; Thwala, W.D.; Rillie, I. Industry 4.0 deployment in the construction industry: A bibliometric literature review and UK-based case study. Smart Sustain. Built Environ. 2020. [CrossRef]

71. Sepasgozar, S.M.E.; Shi, A.; Yang, L.; Shirowzhan, S.; Edwards, D.J. Additive Manufacturing Applications for Industry 4.0: A Systematic Critical Review. Buildings 2020, 10, 231. [CrossRef]

72. Lai, J.H.K. Maintenance performance: Examination of the computer-aided maintenance data of a large commercial building. J. Perform. Constr. Facil. 2015, 29, 04014118. [CrossRef]

73. Barrett, P.; Davies, F.; Zhang, Y.; Barrett, L. The impact of classroom design on pupils' learning: Final results of a holistic, multi-level analysis. Build. Environ. 2015, 89, 118-133. [CrossRef]

74. Howland, J.; Wedman, J. A Process Model for Faculty Development: Individualizing Technology Learning. J. Technol. Teach. Educ. 2004, 12, 239-262.

75. Pärn, E.; Edwards, D.; Sing, M. The building information modelling trajectory in facilities management: A review. Autom. Constr. 2017, 75, 45-55. [CrossRef]

76. Singh, R.; Rosengren, S. Why do online grocery shoppers switch? An empirical investigation of drivers of switching in online grocery. J. Retail. Consum. Serv. 2020, 53, 101962. [CrossRef]

77. Edwards, D.J.; Pärn, E.; Love, P.E.; El-Gohary, H. Research note: Machinery, manumission, and economic machinations. J. Bus. Res. 2017, 70, 391-394. [CrossRef] 